\title{
MANAKAH INDIKATOR TERPENTING STABILITAS SISTEM KEUANGAN? PERSPEKTIF MAKROPRUDENSIAL
}

\section{WHAT IS THE MOST IMPORTANT INDICATOR OF FINANCIAL SYSTEM STABILITY? MACROPRUDENTIAL PERSPECTIVE}

\author{
Aam Slamet Rusydiana ${ }^{1}$, Lina Nugraha Rani ${ }^{2}$, Fatin Fadhilah Hasib ${ }^{3}$ \\ ${ }^{1}$ SMART Indonesia, Jakarta, Indonesia \\ aamsmart@gmail.com \\ ${ }^{2}$ Departemen Ekonomi Islam, Fakultas Ekonomi \& Bisnis Universitas Airlangga, Surabaya, Indonesia \\ linanugraha@feb.unair.ac.id \\ ${ }^{3}$ Departemen Ekonomi Islam, Fakultas Ekonomi \& Bisnis Universitas Airlangga, Surabaya, Indonesia \\ fatin.fadhilah@feb.unair.ac.id
}

\begin{abstract}
Abstrak
Secara umum ada dua indikator stabilitas sistem keuangan di Indonesia, yaitu mikroprudensial dan makroprudensial. Di antara indikator makroprudensial adalah pertumbuhan ekonomi, neraca pembayaran, tingkat inflasi, suku bunga dan nilai tukar, efek penularan krisis, dan banyak lainnya. Berbeda dari penelitian sebelumnya mengenai pengukuran stabilitas sistem keuangan, penelitian ini akan menggunakan perspektif praktisi keuangan dan perbankan mengenai indikator utama dalam mengukur stabilitas sistem keuangan dengan menggunakan Analytic Network Process (ANP) metode. Hasil penelitian menunjukkan bahwa berdasarkan hasil wawancara dengan pakar/ praktisi perbankan, 3 (tiga) aspek terpenting adalah aspek Utang $(0,225)$, Indikator Makro $(0,222)$ dan aspek Neraca Pembayaran $(0,217)$. Indikator penting stabilitas sistem keuangan dari aspek makroprudensial berikutnya terkait dengan Contagion Effect $(0,178)$ dan Aspek Tenaga Kerja $(0,159)$. Kebijakan makroprudensial yang dikeluarkan oleh Bank Indonesia sebagai bank sentral yang memiliki otoritas penuh, memainkan peran penting dalam menjaga Stabilitas Sistem Keuangan (SSK) di Indonesia.
\end{abstract}

Kata kunci: Stabilitas Keuangan, Makroprudensial, ANP

Klasifikasi JEL: E52, E60, G21

\begin{abstract}
The financial system stability of Indonesia is generally measured in two ways, namely microprudential and macroprudential. Among macroprudential indicators they are economic growth, balance of payments, inflation rate, interest and exchange rates, crisis contagion effect, and many others. Different from the previous researches, this research utilises financial and banking practitioners' perspective to determine the leading indicator of financial system stability using Analytic Network Process (ANP) method. The results show that, the three most important indicators of Indonesia's financial stability at macro levels include the Debt-related aspect (0.225), Macroeconomic Indicator (0.222) and the Balance of Payment aspect (0.217). The other important indicators of financial system stability is related to Contagion Effect (0.178) and the Labor-related aspects (0.159). The Macroprudential Policy issued by Bank Indonesia, play an important role in maintaining Financial System Stability (SSK) in Indonesia.
\end{abstract}

Keywords: Financial Stability, Macroprudential, ANP

JEL Classification: E52, E60, G21 


\section{PENDAHULUAN}

Data Bank Indonesia menunjukkan bahwa sektor perbankan menguasai sekitar 79\% dari total aset seluruh industri keuangan. (Statistik Perbankan Indonesia, 2009). Implikasinya, kegagalan sistem perbankan akan sangat berdampak kepada perekonomian Indonesia. Suseno dan Abdulloh (2003) mengatakan bahwa bank merupakan unit usaha yang memiliki ketergantungan sumber dana dari masyarakat dalam kegiatan operasionalnya. Maka, bank dapat berjalan selama ini karena adanya kepercayaan dari masyarakat. Jika kepercayaan ini merosot akan berakibat pada kegagalan sistem perbankan yang bersifat sistemik dan berpotensi mengakibatkan krisis perbankan.

Krisis keuangan yang melanda sebagian besar kawasan Asia tidak terkecuali Indonesia pada tahun 1997-1998 telah membuat perekonomian terperosok tajam. Pada awalnya ditandai dengan melemahnya nilai tukar Bath Thailand terhadap Dolar Amerika Serikat (AS) yang mencapai $-54 \%$. Krisis keuangan ini secara cepat menyebarluas ke beberapa kawasan Asia seperti Korea Selatan, Malaysia Singapura dan Indonesia. Pada saat itu, depresiasi Won terhadap Dolar AS hingga mencapai $-48 \%$, Ringgit Malaysia terdepresiasi sebesar $-40 \%$ terhadap Dolar AS dan Dolar Singapura terdepresiasi sebesar $-19 \%$. (Suta dan Musa, 2003). Sedangkan, nilai tukar Rupiah/USD yang awalnya berada pada kisaran Rp. 2,500 (1997) ketika periode krisis nilainya terpesorok ke titik terendah mencapai Rp.16,500/USD. (Laporan Tahunan Perekonomian Indonesia 1998/1999, BI). Krisis nilai tukar Rupiah ini kemudian secara sistemik meruntuhkan sistem perbankan nasional dan mengakibatkan pertumbuhan ekonomi negatif sebesar $-13.1 \%$ pada tahun 1998. (Bank Indonesia, 2009).

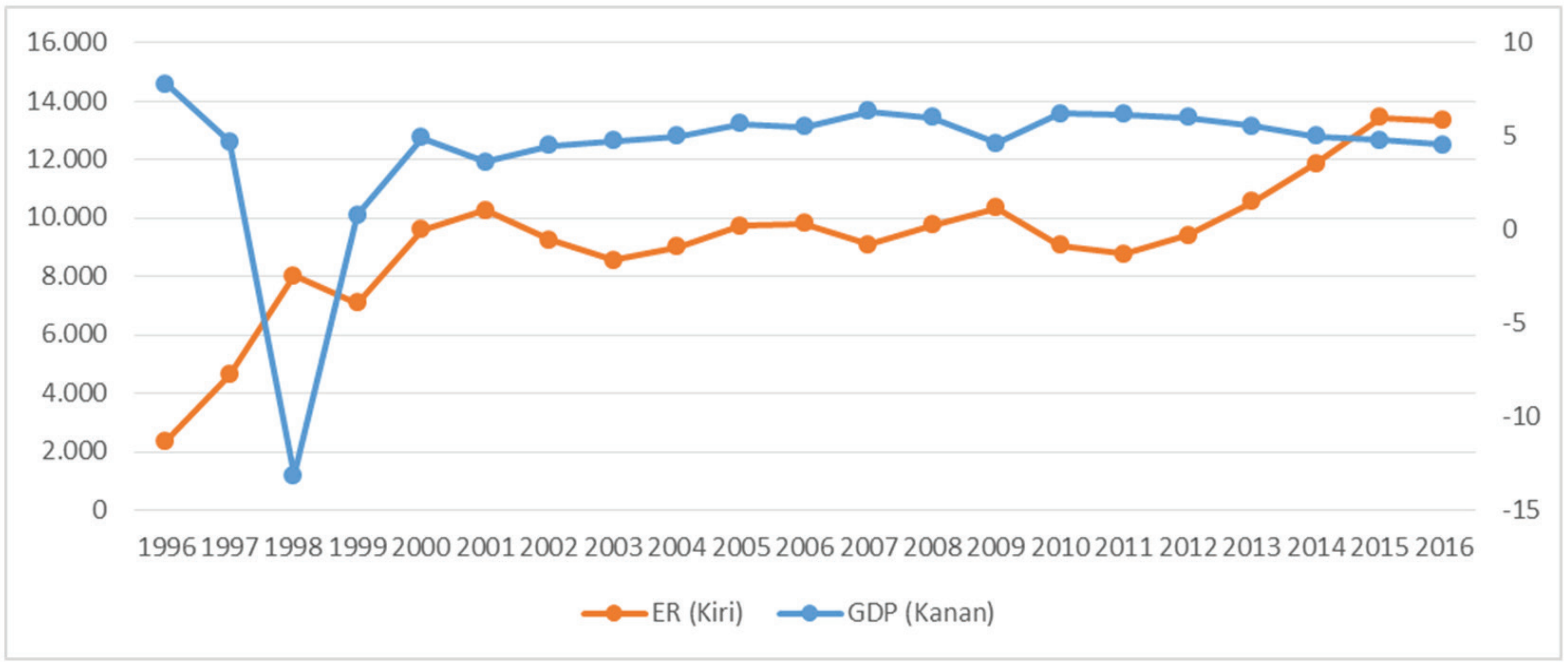

Sumber: IMF dan World Bank, diolah penulis

Gambar 1.1 Grafik Nilai Tukar Rupiah dan Pertumbuhan Ekonomi 1996 - 2016

Krisis nilai tukar rupiah pada tahun 1998 direspon oleh sektor perbankan nasional dengan menaikkan tingkat suku bunga. Overnight call rate meningkat sampai $81 \%$ dan tingkat suku bunga SBI bergerak dari 12\% hingga 30\%. Namun peningkatan suku bunga tersebut tidak dapat menstabilkan kembali nilai tukar Rupiah karena tidak adanya proteksi unhedged foreign exchange exposure berusaha membeli dolar. Pada akhirnya depresiasi nilai tukar rupiah, tingginya tingkat suku bunga, meningkatnya permintaan dolar dan utang luar negeri yang tidak terlindungi (unhegded) menjadikan sebuah kombinasi permasalahan yang berujung pada krisis perbankan (Suta dan Musa, 2003).

Krisis perbankan ini terjadi karena peningkatan suku bunga yang dilakukan pemerintah untuk menstabilkan nilai tukar Rupiah secara otomatis berdampak pada meningkatnya cost of fund, lending rate, dan 
foreign exchange exposure di sektor perbankan. Hal ini mengakibatkan pada masifnya kredit macet (default rate) pada kredit-kredit perbankan, likuiditas perbankan di Indonesia terganggu dan kelangsungan sistem pembayaran nasional pun terancam. (Suta dan Musa, 2003).

Setelah krisis keuangan Asia tahun 19971998, krisis kembali menyerang fundamental ekonomi negara adidaya Amerika Serikat (AS). Pada tahun 2008, AS terkena krisis keuangan yang disebabkan oleh kredit perumahan yang beresiko tinggi. Krisis keuangan ini disebut juga dengan subprime mortgage ${ }^{l}$ (Outlook Ekonomi Indonesia BI, 2009-2014, edisi Januari 2009). Dampak yang terjadi akibat krisis keuangan global ini di AS adalah bangkrutnya beberapa perusahaan investasi pemerintah dan swasta seperti Lehman Brothers, Fannie Mae dan Freddie Mac. Krisis keuangan tahun 2008 ini tidak hanya berdampak kepada perekonomian domestik AS saja, namun juga negara-negara lain yang terintegrasi dengan sistem keuangan AS. Indonesia sendiri tidak luput dari dampak krisis keuangan global ini, pasar modal Indonesia bergejolak, data yang dipublikasikan oleh kementrian keuangan pada januari 2010 menunjukkan adanya ketidakstabilan pada pasar modal di Indonesia.

Dampak krisis keuangan global pada perekonomian Indonesia termanivestasikan pada gejolak pasar modal dan pasar uang melalui penurunan nilai kapitalisasi, volume perdagangan saham, kepemilikan asing pada saham, SUN dan SBI serta depresisasi nilai tukar rupiah terhadap dollar AS. Dampak yang lain yaitu pemodal asing yang memindahkan dananya ke investasi yang aman, merosotnya harga komoditi ekspor sehingga memberikan dampak negatif terhadap dunia usaha yang bergerak di bidang ekspor dan menyebabkan pemutusan hubungan kerja. Penurunan aktifitas dunia usaha, secara sirkular berpengaruh pada penurunan bisnis perbankan (Bank Indonesia, 2009 b).

Pada saat terjadi krisis ekonomi, bank sebagai institusi keuangan sedikit banyak memberi amplitudo pada krisis tersebut. Diketahui bahwa

\footnotetext{
Kredit perumahan (mortgage) yang diberikan kepada debitur dengan sejarah kredit yang buruk atau belum memiliki sejarah kredit sama sekali sehingga digolongkan sebagai kredit yang beresiko tinggi.
}

salah satunya bank-bank di Amerika gagal dalam mematuhi peraturan tentang permodalan. Pelanggaran atas peraturan ini, menurut Norgren (2010) menjadi salah satu penyumbang suatu krisis dapat tercipta. Selain itu, banyaknya inovasi dalam produk keuangan yang merupakan gambaran dari liberalisasi keuangan juga menjadi salah satu faktor, krisis perbankan dan keuangan saling memiliki keterkaitan yang erat setelah adanya liberalisasi keuangan (Kamminsky and Reinhart, 1999).

Pada tataran kebijakan, Indonesia menggunakan dua (2) indikator pengukuran stabilitas sistem keuangan yakni mikroprudensial dan makroprudensial. Indikator mikroprudensial diantaranya adalah: rasio kecukupan modal perbankan, kualitas aset, manajemen sistem keuangan yang sehat, pendapatan dan keuntungan bank, aspek likuiditas, sensitivitas terhadap risiko pasar dan beberapa indikator berbasis pasar. Sementara itu indikator makroprudensial diantaranya: pertumbuhan ekonomi, balance of payment, tingkat inflasi, suku bunga dan nilai tukar, contagion effect atau efek menular krisis, serta faktor-faktor lain.

Dampak krisis keuangan global yang mengancam kestabilan sistem keuangan di Indonesia menjadi perhatian besar bagi pemerintah Republik Indonesia. Pemerintah Republik Indonesia pada tanggal 17 Maret 2016 telah mengesahkan Undang-Undang (UU) Nomor 9 Tahun 2016 tentang Pencegahan dan Penanganan Krisis Sistem Keuangan (UU PPKSK).

Berbeda dengan penelitian-penelitian sebelumnya terkait pengukuran stabilitas sistem keuangan yang lebih banyak menggunakan pendekatan kuantitatif(Goldstein, 2000; Ascarya et.al, 2012; Hardy \& Pazarbasioglu, 1999), dalam penelitian ini akan mencoba melihat dari perspektif praktisi keuangan dan perbankan terkait manakah indikator terpenting (leading indicator) dalam pengukuran stabilitas sistem keuangan sehingga diharapkan kita mampu mengetahui apa sesungguhnya indikator utama stabilitas keuangan dari realitas yang dihadapi. Hal ini menjadi urgen dilakukan karena mayoritas penelitian terkait tema ini adalah berupa riset kuantitatif. Sementara kita perlu melihat perspektif lain dari para praktisi 
keuangan akan realitas sesungguhnya terkait stabilitas sistem keuangan.

Dari latar belakang tersebut, beberapa tujuan penelitian yang akan dikaji oleh penulis: 1). Mengidentifikasi indikator utama (leading indicator) krisis keuangan aspek makroprudensial dari perspektif praktisi expert, 2). Merumuskan rekomendasi yang tepat yang dapat ditawarkan dalam kerangka stabilitas sistem keuangan.

\section{TINJAUAN PUSTAKA}

Kaminsky et.al (1997) mendefinisikan krisis perbankan sebagai suatu situasi di mana serangan pada sistem nilai tukar menyebabkan depresiasi tajam pada nilai tukar tersebut, atau bisa juga mengakibatkan penurunan drastis dalam cadangan devisa asing (international reserves) atau bahkan kombinasi antar keduanya. Menurut Frankel dan Rose (1996) krisis keuangan adalah perubahan besar padabeberapa indikator pada nilai potensial atau aktual dari sebuah mata uang. Untuk itu harus diteliti episode depresiasi besar-besaran tersebut, kapan otoritas mampu menahan dan kapan tidak. Dalam situasi seperti apa mereka muncul, dan faktor apa yang menyebabkan situasi menjadi sulit dikendalikan.

Menurut Kaminsky, Lizondo dan Reinhart (2000) krisis yang melanda negara-negara disebabkan oleh beberapa indikator di antaranya adalah neraca pembayaran, pertumbuhan ekonomi, inflasi, nilai tukar, suku bunga dan jumlah uang beredar. Indikator-indikator tersebut dapat dijadikan sebagai indikator deteksi dini terhadap rawannya krisis. Multi krisis yang terjadi di Indonesia pada tahun 1998, pada awalnya disebabkan oleh nilai tukar rupiah yang terdepresiasi tajam terhadap mata uang dollar Amerika. Hal ini ditambah dengan suku bunga perbankan yang meningkat tajam, maka terjadilah kredit macet yang disebabkan oleh banyaknya peminjam tidak dapat mengembalikan dana pinjamannya ke bank, selain itu pun terjadi rush besar-besaran sehingga menyebabkan likuiditas perbankan terganggu.

Berulang-ulang krisis yang melanda setiap negara dan dampaknya yang sangat merugikan perekonomian, membuat para peneliti ingin melakukan penelitian tentang penyebab awal krisis ini terjadi atau indikator peringantan dini (IPD) yang menyebabkan krisis. Penelitian yang dilakukan oleh Abimanyu dan Imansyah (2008), dengan menggunakan model signal dan menggunakan rata - rata indeks krisis ditambah 2 standar deviasi menunjukkan bahwa krisis keuangan yang terjadi di Indonesia pada periode 1970-1997 menghasilkan sebanyak 4 kali periode krisis yaitu pada bulan November 1978, April 1983, September 1986 dan Agustus 1997. Secara teori terdapat 4 teori tentang analisis krisis keuangan di antaranya: teori generasi pertama, teori generasi kedua, teori generasi ketiga dan teori di luar dari tiga generasi tersebut. Berikut ketiga teori generasi dalam (Krznar, 2004):

Model Generasi Pertama. Krisis generasi pertama (The First Generation of Crisis) adalah krisis nilai tukar atau krisis neraca pembayaran yang dialami oleh satu negara dengan perekonomian terbuka, berukuran kecil, dan menerapkan rezim nilai tukar tetap (fixed exchange rate).Teori ini diperkenalkan oleh Salant dan Henderson (1978), yang kemudian dikembangkan oleh Krugman (1979) di mana krisis finansial dengan melihat krisis neraca pembayaran, jatuhnya nilai tukar mata uang akibat ekspansi kredit domestik oleh bank sentral adalah tidak konsisten dengan target nilai tukar mata uang.

Model Generasi Kedua. Krisis generasi kedua (The Second Generation of Crisis) merupakan krisis neraca pembayaran yang terjadi di tengah fundamental perekonomian yang tergolong kuat. Krisis ini juga dilatarbelakangi oleh negara yang menganut sistem nilai tukar tetap. Model krisis generasi kedua yang dikembangkan Obstfeld (1996). Dalam model ini peran sentral ekspektasi dan kegagalan koordinasi antar kreditur menjadi penyebab krisis walaupun fundamental ekonomi suatu negara tergolong sehat. Ketika investor berspekulasi apakah pemerintah akan mengendalikan kursnya atau tidak, maka model ini akan menunjukkan sebuah keseimbangan, di mana serangan spekulasi tersebut akan tercipta dengan sendirinya. Artinya, tujuan investor menyerang mata uang adalah agar investor lain pun menyerang mata uang tersebut. Menurut Ozkhan dan Sutherland (1995) menunjukkan bahwa otoritas moneter akan tidak setuju untuk 
mempertahankan kurs dengan tingkat suku bunga yang tinggi dalam serangan spekulasi jika tingkat pengangguran pun tinggi karena hal ini akan menyebabkan pengangguran yang lebih meningkat lagi.

Model Generasi Ketiga. Model generasi ketiga (The Third Generation of Crisis) menyatakan bahwa penyebab krisis keuangan adalah karena efek penularan (contagion effect). Krisis ini menjalar melalui hubungan perdagangan ketika depresiasi terjadi di suatu negara menjadikan penurunan daya saing untuk negara lain. Ketergantungan antar negara dapat memberikan peranan terhadap krisis ketika ketidakmampuan suatu negara untuk membayar utang luar negeri yang memaksa kreditor asing untuk mencabut pinjamannya juga di negara lain. Ali (2007) mengatakan bahwa model ini memfokuskan pada efek neraca yang terkait dengan devaluasi mata uang. Di mana bank-bank dan perusahaan-perusahaan di negara berkembang memiliki ketidaksesuaian mata uang, mereka melakukan pinjaman dengan mata uang asing dan memberikan pinjaman dengan mata uang lokal. Sehingga akan menimbulkan resiko kredit akibat devaluasi nilai tukar mata uang.

Model Di luar Sistem Generasi. Salah satu model yang berada diluar sistem generasi adalah model Kindleberger-Minsky yang menjelaskan tiga tahapan dalam krisis keuangan: mania, panik, dan runtuh (collapse). Mania adalah periode upswing dalam siklus bisnis ketika pelaku pasar merestruktur aset-aset mereka yang lebih mengarah pada aset finansial dan riil. Panik dicirikan oleh pengaruh dorongan dan persaingan dalam transformasi aset finansial dan riil ke dalam bentuk aset yang paling likuid. Runtuh (collapse) adalah tahap akhir dari proses (Imansyah, 2009). Saqib (2002) menyatakan bahwa krisis bisa saja dimulai dari luar sistem keuangan seperti perang, politik dan lain-lain yang dapat memberikan dampak yang kuat bagi ekspektasi peningkatan dan penurunan ekonomi di satu sektor.

\section{Studi Terdahulu}

Penelitian yang berkaitan dengan indikator terjadinya sebuah krisis khususnya krisis perbankan telah banyak dilakukan. Beberapa studi tersebut antara lain, Kunt \& Detragiache (1998),
Shen \& Hsienh (2003), Hadad et. al (2003), Ali (2007), Boyd et. al (2009), Barrel (2010), dan Bucevka (2011). Dalam penelitian berjudulThe Determinants of Banking Crises in Developing and Developed Countries, Kunt \& Detragiace (1998) menjelaskan mengenai faktor-faktor yang menentukan terjadinya krisis perbankan. Faktor-faktor tersebut diataranya adalah faktor makroekonomi (growth, perubahan TOT (Term of Trade), depresiasi, real interest rates, tingkat inflasi, surplus budget terhadap GDP), finansial (rasio M2 terhadap cadangan devisa, rasio bank cash dan reserves terhadap bank assets, pertumbuhan kredit) dan institusional.

Chung-Hua Shen dan Meng-Fen Hsienh (2003) dalam penelitiannya mengombinasikan pendekatan makro dan mikro sebagai modifikasi dalam early warning system untuk memonitor kemungkinan perbankan terkena krisis. Hasil dari penelitian tersebut adalah; (a) Indikator mikro yang kuat adalah non-interest expenses/ total assets dan ROA, sedangkan indikator mikro yang rentan terhadap kegagalan perbankan adalah ekuitas yang melebihi total aset, (b) Indikator NPL yang secara khas dipercaya bermanfaat sebagai indikator kegagalan perbankan, ternyata tidak informatif bagi pihak luar. (c) Indikator makro yang dapat dijadikan indikator kuat adalah tingkat pertumbuhan GDP dan Exchange Rate, sedangkan indikator yang lemah adalah kredit perbankan dan Utang Luar Negeri Jangka Pendek. M2/FR ternyata tidak memberikan kontribusi meskipun studi lain menyatakan indikator tersebut berpengaruh.

Sementara itu Hadad, Santoso, dan Arianto (2003) menjelaskan setidaknya terdapat enam indikator untuk melihat potensi krisis perbankan, diantaranya adalah: GDP riil yang melambat, konsumsi swasta yang melambat, penurunan tingkat investasi, depresiasi yang tajam pada nilai tukar, pemberian kredit kepada sektor swasta yang semakin intensif, dan penurunan jumlah simpanan yang berkelanjutan.

Barrel, Davis, Karim, dan Liadze (2010) dalam penelitiannya pada 2007 menyimpulkan; (a) CAR perbankan, Liquiditas Perbankan dan harga Properti memiliki dampak yang signifikan dalam menentukan tingkat kemungkinan krisis perbankan terjadi dan variabel ini lebih tradisional 
dibandingkan GDP Growth, Inflasi, dan Real Interest Rate. Oleh karena itu, model ini dapat digunakan untuk mendeteksi kemungkinan terjadinya krisis perbankan. (b) CAR yang tinggi diiringi rasio likuiditas mampu mengindikasiskan kemungkinan terjadinya krisis perbankan, berimplikasi jangka panjang untuk menutup kerugian dari biaya yang ditentukan oleh peraturan.

Sementara Bucevska (2011) menghasilkan penelitian dengan kesimpulan sebagai berikut; (a) DEBT, LOANS, dan DEPOSITS adalah tiga indikator utama Early Warning Sistem dalam pemprediksi krisis finansial di Kroasia, Macedonia, dan Turki. Selain itu REER, Defisit Current Account, Defisit Fiskal, dan PORTFOLICHANGE secara statistik sangat berpengaruh signifikan dalam krisis keuangan di negara-negara Uni Eropa. (b) Negara-negara EU harus mengurangi utang luar negeri yang berkaitan dengan GNP dan secara kontinyu menganalisis dan memonitor lebih dekat proses finansial di negaranya untuk mengantisipasi terjadinya krisis yang sama.

Penelitian lainnya dilakukan oleh Ascarya (2009) dengan judul Lessons Learned from Repeated Finansial Crises: An Islamic Economic Perspective. Penelitian ini membandingkan kontribusi sistem moneter konvensional (fiat money, fractional reserves banking system, dan interest) dengan sistem moneter Islam (gold money, fully reserves banking system, dan profit loss sharing). Dengan menggunakan metodologi VAR/VECM, variabel dependen yang digunakan adalah Inflasi. Hasil dari penelitian ini menunjukkan bahwa sistem moneter konvensional berkontribusi terhadap terjadinya krisis dibanding sistem moneter Islam.

Imansyah (2004) dalam penelitiannya menyimpulkan bahwa variabel yang penting untuk menentukan kemungkinan terjadinya krisis adalah Ekspor, Nilai tukar riil, rasio defisit fiskal terhadap PDB dan harga minyak dunia. Model yang dikembangkannya mampu meramalkan krisis 1998 dan krisis yang terjadi pada masa datang yaitu krisis mini tahun 2005 dan krisis yang terjadi tahun 2008 .

Dari uraian diatas, maka dapat disimpulkan bahwa suatu krisis dapat diindikasikan melalui faktor mikro (perbankan) dan faktor makro (makroekonomi). Kunt (1998), Shen (2003) Hadad at. al (2003), Boyd et. al (2009), dan Barrel (2010) menyebutkan bahwa faktor pertumbuhan GDP menjadi indikator makroekonomi yang paling penting dalam mengindikasikan kemungkinan terjadi krisis. Selain itu, inflasi, Exchange Rate, Interest Rate, dan Investasi dapat pula dijadikan indikator kemungkinan terjadinya krisis. Sedangkan indikator mikro ditentukan oleh kredit yang disalurkan perbankan (Hadad, 2003; Ali, 2008; dan Bucevka, 2011). Adapun Kunt (1998) dan Boyd et al (2009) menyebutkan bahwa interest rate dapat menyebabkan krisis perbankan menjadi sistemik. Mayoritas studi menggunakan pendekatan kuantitatif dan pemodelan ekonometrik. Relatif jarang studi terkait identifikasi indikator penting stabilitas sistem keuangan dengan pendekatan kualitatif, terutama berdasarkan persepsi langsung para praktisi industri keuangan dan perbankan. Penelitian ini mencoba mengisi gap tersebut.

\section{METODE PENELITIAN}

Data yang digunakan dalam analisis ini adalah data primer yang didapat dari hasil wawancara (indepth interview) dengan dengan pakar dan praktisi, yang memiliki pemahaman tentang permasalahan yang terkait dengan stabilitas sistem keuangan Indonesia. Pemilihan responden expert dari industri perbankan karena studi ini memang fokus ingin melihat persepsi praktisi. Data dikumpulkan melalui pengisian kuesioner pada pertemuan kedua dengan responden. Untuk detail faktor-faktor yang termasuk dalam model berdasarkan wawancara dengan para responden expert, dapat dilihat pada lampiran.

Secara umum, variabel makroprudensial yang masuk ke dalam model ANP dalam penelitian ini terbagi menjadi 5 aspek yakni: (1) Neraca pembayaran atau balance of payment, (2) Indikator makroekonomi, (3) Efek domino (contagion effect), (4) Utang, dan (5) Aspek tenaga kerja. Masing-masing variabel terdiri dari beberapa indikator yang diambil dan dikumpulkan berdasarkan studi terdahulu yang telah penulis lakukan. 
Pemilihan responden pada penelitian dilakukan dengan mempertimbangkan pemahaman responden terhadap stabilitas sistem keuangan di Indonesia. Jumlah responden dalam penelitian ini terdiri dari tujuh (7) orang pakar yang merupakan praktisi perbankan/keuangan dengan pertimbangan berkompeten. Ketujuh pakar berasal dari level manajemen menengah ke atas yang berasal dari bank konvensional berjumlah 3 orang, bank syariah 3 orang dan 1 orang dari Bank Indonesia.

Syarat responden yang valid dalam ANP adalah bahwa mereka adalah orang-orang yang menguasai atau ahli di bidangnya. Oleh karena itu, responden yang dipilih dalam survey ini adalah para praktisi perbankan/keuangan di Indonesia. Penelitian ini merupakan penelitian analisis kualitatif-kuantitatif dimana bertujuan untuk menangkap suatu nilai atau pandangan yang diwakili para pakar. Alat analisis yang digunakan adalah metode ANP dan diolah dengan menggunakan software "Super Decision".

Analytic Network Process (ANP) merupakan teori matematis yang mampu menganalisa pengaruh dengan pendekatan asumsi-asumsi untuk menyelasaikan bentuk permasalahan. Metode ini digunakan dalam bentuk penyelesaian dengan pertimbangan atas penyesuaian kompleksitas masalah secara penguraian sintesis disertai adanya skala prioritas yang menghasilkan pengaruh prioritas terbesar. ANP juga mampu menjelaskan model faktor-faktor dependence serta feedbacknya secara sistematik. Pengambilan keputusan dalam aplikasi ANP yaitu dengan melakukan pertimbangan dan validasi atas pengalaman empiris.

Tahapan pada metode ANP antara lain meliputi konstruksi dan kuantifikasi model. Konstruksi model ANP disusun berdasarkan literature review secara teori maupun empiris dan memberikan pertanyaan pada pakar dan praktisi perbankan/keuangan serta melalui indepth interview untuk mengkaji informasi secara lebih dalam untuk memperoleh permasalahan yang sebenarnya.

Tahap kuantifikasi model menggunakan pertanyaan dalam kuesioner ANP berupa pairwise comparison (pembandingan pasangan) antar elemen dalam cluster untuk mengetahui manadiantara keduanya yang lebih besar pengaruhnya (lebih dominan) dan seberapabesar perbedaannya melaluiskala numerik 1-9. Data hasil penilaian kemudian dikumpulkan dan diinput melalui software super decision untuk diproses sehingga menghasilkan output berbentuk prioritas dan supermatriks. Hasil dari setiap responden akan diinput pada jaringan ANP tersendiri ${ }^{2}$. Untuk menyortir, penulis mengkombinasikan metode ANP dengan teknik Delphi, sehingga elemen-elemen yang ada dalam model diharapkan merupakan variabel yang memiliki tingkat bobot kepentingan yang besar. Selanjutnya, untuk mempermudah interview dan menjaga tingkat konsistensi ANP, penulis menggunakan framework kuesioner yang dikenalkan oleh Ascarya (2015).

Untuk mendapatkan bobot eigenvalue yang menjadi hasil akhir analisis ANP, perlu dilakukan beberapa tahap dari supermatriks. Misalkan $\mathrm{A}_{1}$, $\mathrm{A}_{2}, \mathrm{~A}_{3}, \ldots, \mathrm{A}_{\mathrm{n}}$ adalah $\mathbf{n}$ elemen suatu matriks didalam suatu hierarki. Pembandingan pasangan dari elemen-elemen $\left(\mathrm{A}_{\mathrm{i}}, \mathrm{A}_{\mathrm{j}}\right)$ yang harus kita lakukan dicerminkan oleh $\mathbf{A}=\left(\mathrm{a}_{\mathrm{ij}}\right)$, matriks $\mathrm{n} \times \mathrm{n}$, dimana $\mathrm{i}, \mathrm{j}=1,2,3, \ldots, \mathrm{n}$. Definisikan suatu set bobot numerik $\mathrm{w}_{1}, \mathrm{w}_{2}, \mathrm{w}_{3}, \ldots, \mathrm{w}_{\mathrm{n}}$ yang mencerminkan perbandingan yang diperoleh, sehingga dapat dituliskan sebagai berikut:

$$
\begin{aligned}
& \begin{array}{lll}
A_{1} & A_{2} & A_{n}
\end{array}
\end{aligned}
$$

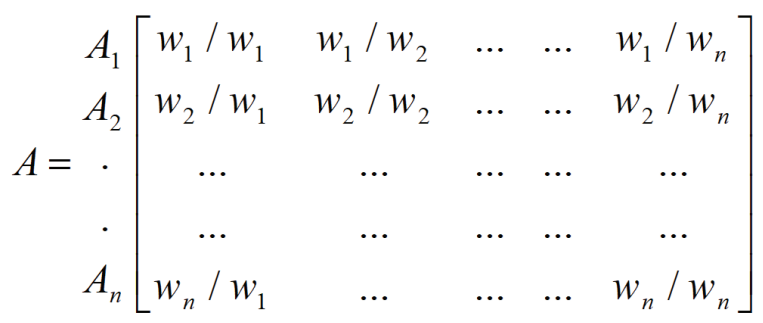

Dalam praktiknya, penggunaan metode ANP dalam riset sangat bervariatif pada berbagai bidang, seperti yang disampaikan oleh Sipahi \& Timor (2010), Rusydiana (2016), Lee (2010), Rusydiana \& Devi (2013), dan Ho (2008) serta Rusydiana dan Devi (2018).

\footnotetext{
${ }^{2}$ Ascarya, 2011,"The Persistence of Low Profit and Loss Sharing Financing in Islamic Banking: The Case of Indonesia"review of Indonesian economic and business studies vol.1 LIPI economic research center.
} 


\section{HASIL DAN PEMBAHASAN}

Berdasarkan hasil analisis ANP, dari perspektif kriteria terkait indikator terpenting stabilitas sistem keuangan menurut pendapat para praktisi perbankan, dalam aspek makroprudensial, yang menjadi 3 (tiga) aspek terpenting adalah aspek Utang $(0,225)$, Indikator Makroekonomi $(0,222)$ dan aspek Neraca pembayaran $(0,217)$. Indikator penting stabilitas sistem keuangan dari aspek makroprudensial selanjutnya adalah terkait Contagion Effect $(0,178)$ dan terakhir Aspek Tenaga Kerja $(0,159)$. Berikut ini adalah bobot eigenvalue lengkap aspek makroprudensial terkait indikator terpenting stabilitas sistem keuangan di Indonesia. Angka 1 hingga 7 menunjukkan nilai bobot dari masing-masing ketujuh pakar yang menjadi informan. Sementara angka 8 adalah ratarata bobot dari ketujuh pakar tersebut. Demikian pula seterusnya.

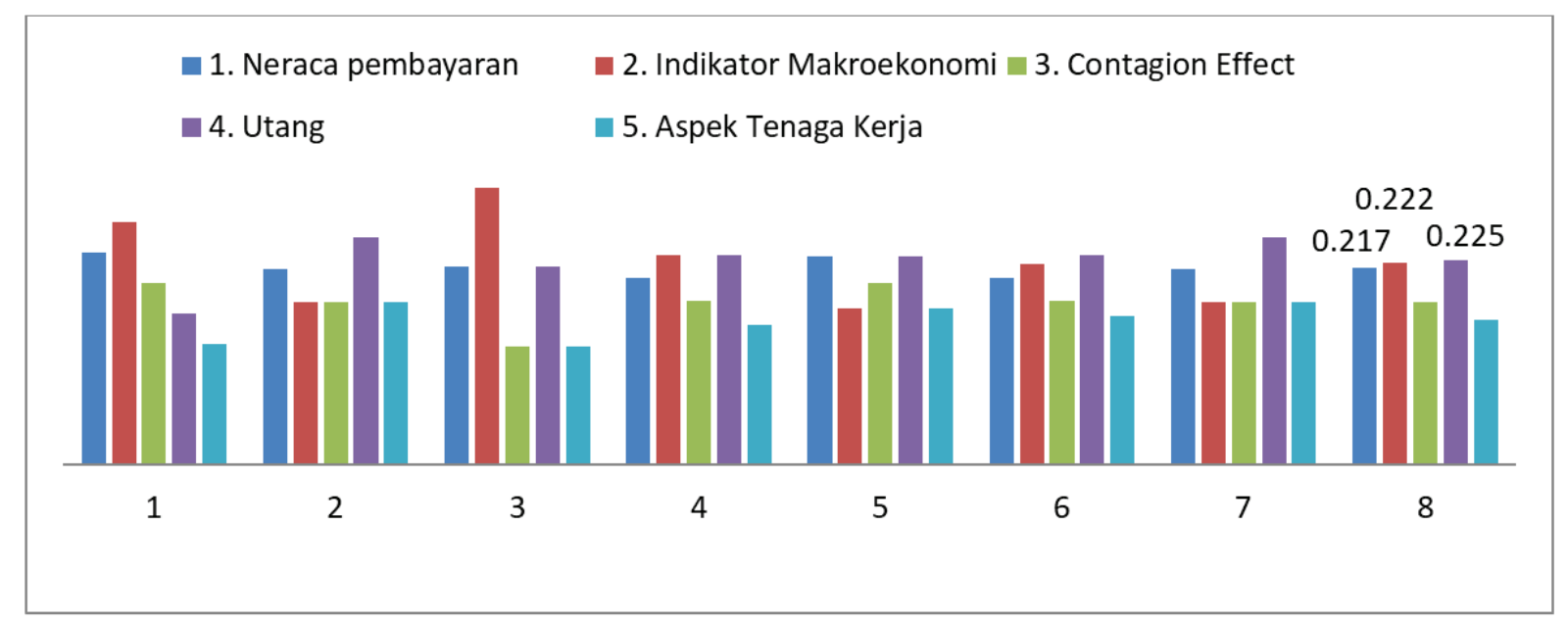

Gambar 4.1 Aspek Makroprudensial Stabilitas Sistem Keuangan

\section{Neraca Pembayaran}

Hasil menunjukkan bahwa dari 5 (lima) indikator Neraca pembayaran, bobot terbesar adalah Defisit Neraca Berjalan (0,230), dan
Kecukupan Cadangan Devisa (0,220). Berikutnya adalah Komposisi \& Jangka Waktu Aliran Modal $(0,198)$, Nilai Ekspor-Impor $(0,192)$ dan Term of Trade/ToT $(0,161)$.

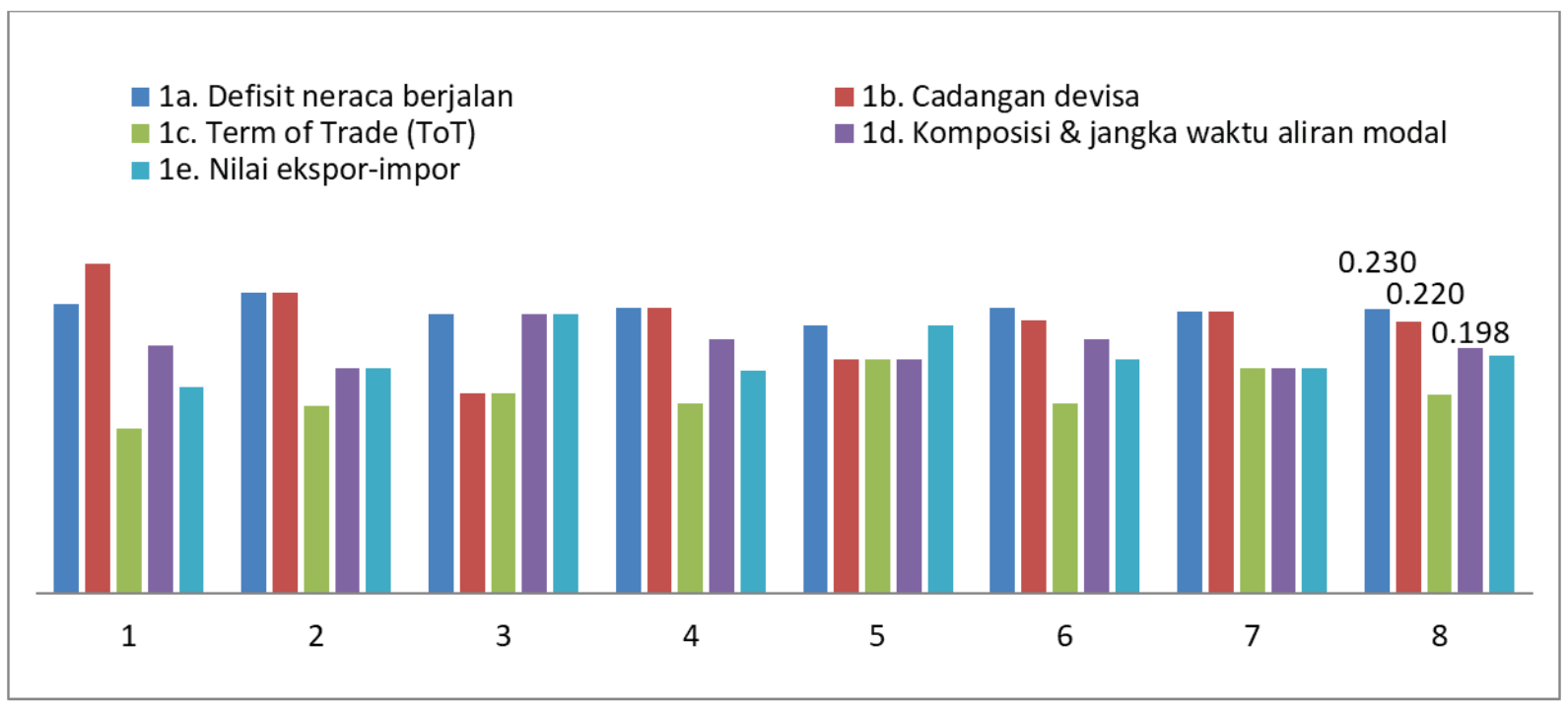

Gambar 4.2 Indikator Neraca Pembayaran 
Neraca berjalan adalah bentuk neraca yang mencatat transaksi barang, jasa, hibah, pendapatan faktor produksi (dari aset dan tenaga kerja) baik dari individu dan pemerintah serta kegiatan transfer uang pada aktifitas perdagangan internasional pada jangka waktu satu tahun. Defisit neraca berjalan (Current Account Defisit) adalah kondisi ketika negara dalam posisi sebagai peminjam dari negara lain sehingga membutuhkan modal untuk membiayai defisit dimaksud. Neraca berjalan pada sebuah negara dapat digambarkan kegiatan ekspor impor. Menurut Beck (2002) negara yang memiliki perkembangan sistem keuangan yang bagus memiliki tingkat ekspor tinggi dan keseimbangan perdagangan barang. Maka jika terdapat defisit dapat menurunkan kinerja sistem keuangan. Penelitian Becker and Greenberg (2005) juga menunjukkan bahwa semakin meningkat perkembangan sistem keuangan akan menyebabkan meningkatnya tingkat ekspor. Hal ini menunjukkan bahwa sistem keuangan dan kegiatan perdagangan internasional saling memengaruhi satu sama lain.

Menurut Boljanovic (2012) defisit transaksi berjalan adalah hasil dari ketidakseimbangan antara tabungan domestik dan investasi yang dapat, di satu sisi, mencerminkan kegiatan investasi yang meningkat yang melebihi tabungan domestik (dan menciptakan kondisi untuk kewajiban pembayaran utang masa depan) atau meningkatnya konsumsi domestik, yang menghasilkan akumulasi utang yang tidak bisa ditangani dengan baik. Defisit neraca berjalan dianggap berkelanjutan jika defisit tidak mengarah pada munculnya krisis sektor eksternal. Krisis sektor eksternal dapat muncul dalam bentuk krisis mata uang atau krisis yang terkait dengan utang luar negeri.

Cadangan devisa atau disebut dengan International Reserves and Foreign Currency Liquidity (IRCL) atau Offical Reserve Assets adalah seluruh aktiva luar negeri yang dikuasai oleh otoritas moneter dan dapat digunakan setiap waktu, guna membiayai ketidakseimbangan neraca pembayaran dan dalam rangka menjaga stabilitas moneter dengan melakukan intervensi di pasar valuta asing serta untuk tujuan lainnya (Kebanksentralan BI, 2006) sehingga dapat dikatakan bahwa cadangan devisa memiliki dua fungsi, yaitu: untuk membiayai ketidakseimbangan neraca pembayaran dan untuk menjaga stabilitas ekonomi. Dalam kaitannya dengan neraca pembayaran, cadangan devisa biasanya digunakan untuk membiayai impor dan kewajiban luar negeri, sementara fungsi lainya untuk menjaga kestabilan moneter adalah untuk mempertahankan nilai tukar mata uang. Besar-kecilnya akumulasi cadangan devisa suatu negara ditentukan oleh kegiatan perdagangan (ekspor dan impor) serta arus modal negara tersebut. Sedangkan kecukupan cadangan devisa ditentukan oleh besarnya kebutuhan impor dan sistem nilai tukar yang digunakan.

Keseimbangan aktivitas ekspor dan impor di Indonesia secara tidak langsung memengaruhi stabilitas ekonomi dan sistem keuangan Indonesia. Keseimbangan nilai ekspor dan impor dapat dilihat dalam perhitungan TOT, yaitu rasio nilai ekspor terhadap nilai impor. semakin besar nilai TOT menandakan semakin besar aktivitas ekspor terhadap impor dan sebaliknya. Nilai impor yang lebih tinggi dari nilai ekspor menandakan bahwa aliran mata uang domestik yang keluar lebih banyak daripada aliran mata uang domestik yang masuk. Selanjutnya, hal ini dapat menyebabkan terdepresiasinya mata uang domestik terhadap mata uang asing (Simorangkir dan Suseno, 2014: 13) sehingga dapat mengganggu stabilitas ekonomi dan keuangan di Indonesia. Hasil dari penghitungan TOT dipengaruhi oleh kurs mata uang domestik terhadap mata uang asing.

\section{Indikator Makroekonomi}

Makro ekonomi mencerminkan kondisi ekonomi secara keseluruhan dalam skala makro. Kondisi ekonomi secara makro secara tidak langsung berpengaruh pada stabilitas sistem keuangan dan sebaliknya. Hal ini dapat kita lihat salah satu kasusnya pada krisis ekonomi di masa lalu. Kedua hal tersebut saling memengaruhi. Salah satu contohnya dapat kita lihat selama krisis ekonomi di masa lalu. Berdasarkan hasil penelitian ini, terdapat tujuh indikator makro ekonomi yang mempunyai dampak langsung terhadap stabilitas keuangan di Indonesia. Dari tujuh indikator makro ekonomi kaitannya dengan stabilitas sistem keuangan di Indonesia, tiga variabel 
dengan hasil bobot terbesar adalah Volatilitas Nilai Tukar $(0,157)$, Pertumbuhan Ekonomi yang rendah $(0,156)$, dan Volatilitas Suku Bunga $(0,154)$. Selanjutnya, variabel makro dengan bobot terbesar adalah Suku Bunga The Fed $(0,142)$, Volatilitas Inflasi $(0,137)$, Inflasi rumah tangga $(0,129)$ dan terakhir adalah Suku Bunga Domestik $(0,125)$.

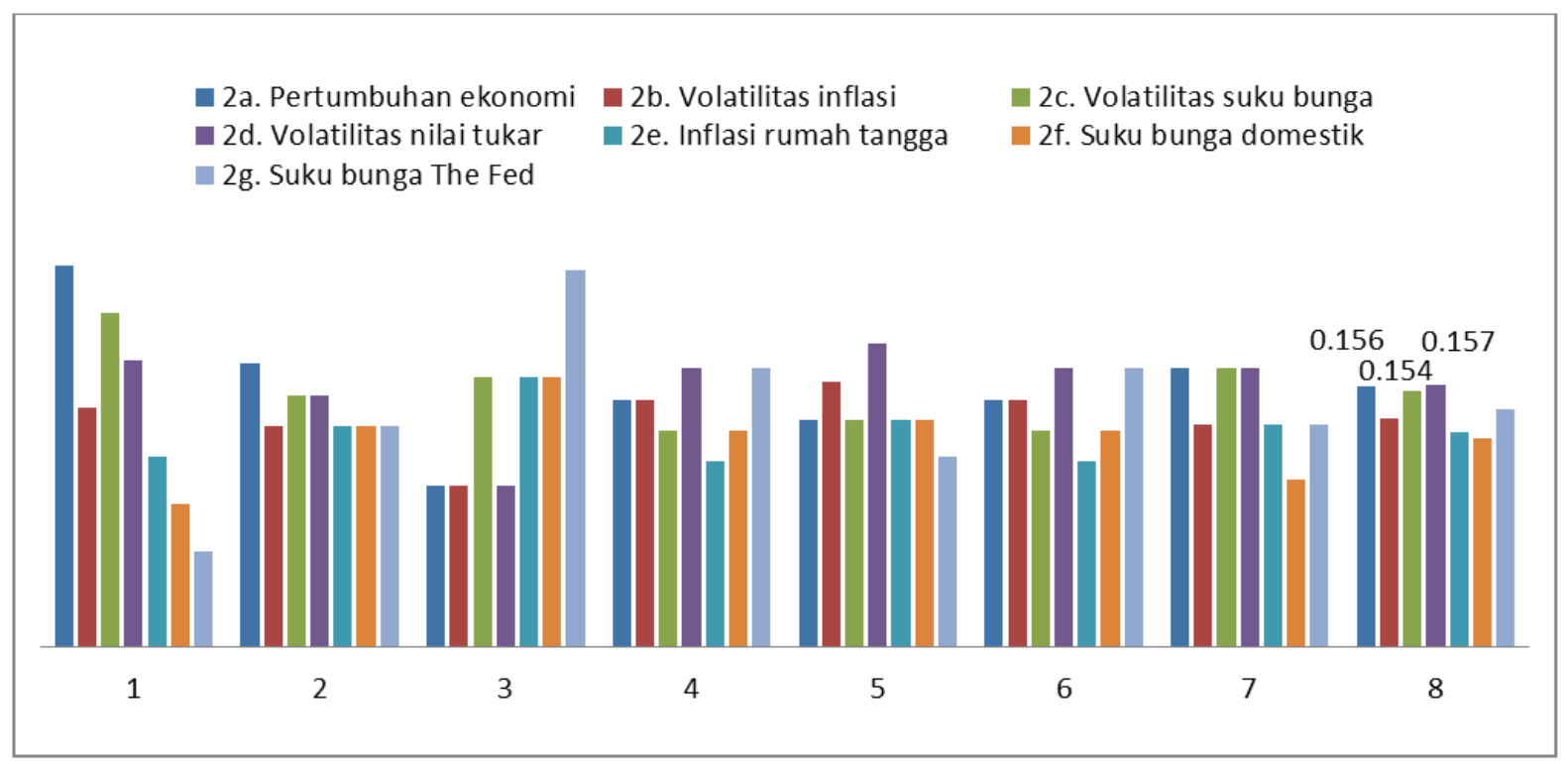

Gambar 4.3 Indikator Makro

Variabel-variabel makroekonomi tersebut saling berkaitan satu sama lain. Volatilitas nilai tukar mata uang merupakan variabel makroekonomi yang memiliki pengaruh paling besar. Volatilitas nilai tukar mata uang berkaitan dengan permintaan dan penawaran mata uang domestik terhadap mata uang asing. Jika permintaan mata uang asing lebih besar daripada permintaan mata uang domestik, maka akan menyebabkan depresiasi mata uang domestik. Jika depresiasinya terlalu dalam maka akan berdampak kepada ketidakstabilan ekonomi. Salah satu faktor yang menyebabkan permintaan mata uang asing lebih besar adalah transaksi atau aktivitas-aktivitas yang menyebabkan banyaknya aliran mata uang domestik ke luar negeri, salah satunya impor (Simorangkir dan Suseno, 2004: 6). Jumlah uang domestik yang beredar di masyarakat mengalami peningkatan. Seiring berjalannya waktu, ketika nilai tukar mata uang domestik mengalami pelemahan maka hal ini dapat mengakibatkan harga-harga barang impor (selanjutnya berdampak pada harga barang konsumsi dalam negeri) membumbung tinggi, memicu terjadinya inflasi, dan pertumbuhan ekonomi akan mengalami penurunan yang selanjutnya akan mengakibatkan kontraksi perekonomian yang cukup mendalam.

Selanjutnya, volatilitas nilai tukar mata uang akan berdampak pada volatilitas tingkat suku bunga domestik. Untuk menyeimbangkan dampak yang diakibatkan oleh volatilitas nilai tukar mata uang maka otoritas moneter menggunakan instrument bunga. Dalam hal ini, Bank Indonesia mempunyai kewenangan untuk menentukan tingkat suku bunga acuan, dimana tingkat suku bunga acuan ini selanjutnya akan memengaruhi penetapan tingkat suku bunga simpanan dan kredit pada bank-bank komersial. Hal ini dilakukan untuk menjaga stabilitas mata uang dan selanjutnya berdampak pada pemeliharaan stabilitas sistem keuangan. Ketika nilai tukar mata uang domestik mengalami depresiasi terhadap mata uang asing, Bank Indonesia cenderung akan menaikkan tingkat suku bunga acuan untuk mengontrol jumlah uang domestik yang beredar di masyarakat. Selanjutnya, bank-bank komersial akan menyesuaikan diri atas penetapan suku bunga acuan tersebut.

Selain itu, melemahnya nilai tukar mengakibatkan semakin besarnya kewajiban 
utang luar negeri perusahaan-perusahaan sehingga neraca perusahaan dan bank-bank memburuk (Simorangkir dan Suseno, 2004: 3). Dari sinilah secara tidak langsung, volatilitas nilai tukar mata uang akan berpengaruh pada stabilitas sistem keuangan. Oleh karena itu, sesuai dengan Undang-Undang No. 4 tahun 2003, Bank Indonesia mempunyai tugas untuk menjaga dan memelihara kestabilan nilai Rupiah. Bank Indonesia tidak hanya menjaga kestabilan nilai Rupiah agar harga barang dan jasa (tingkat inflasi) dapat terkendali, tetapi juga untuk menjaga stabilitas nilai Rupiah terhadap mata uang asing.

Diaconu dan Oanea (2014) menganalisis hubungan antara indikator makroekonomi yang diproksikan dengan pertumbuhan GDP dan tingkat inflasi; kondisi pasar keuangan yang diproksikan dengan BET rate; dan sektor perbankan yang diproksikan dengan interbank offering rate for 3 months terhadap stabilitas keuangan pada industri perbankan di Romania selama krisis keuangan. Dalam penelitiannya, Diaconu dan Oanea (2014) membagi dalam dua model, yaitu pada bank komersial dan bank koperasi. Hanya indikator pertumbuhan GDP dan interbank offering rate for 3 months yang memberikan dampak signifikan dengan arah positif pada stabilitas keuangan pada bank koperasi. Sebaliknya, tidak ada satupun indikator tersebut yang memberikan dampak yang signifikan pada stabilitas keuangan bank komersial. Selain itu, Rusydiana (2009) menyebutkan bahwa inflasi merupakan salah satu indikator penting stabilitas sistem keuangan di Indonesia.

\section{Efek Domino}

Contagion effect (efek yang bersifat menular) adalah suatu fenomena ketika krisis keuangan yang terjadi pada suatu negara akan memicu terjadinya krisis keuangan atau ekonomi pada negara lain. Contagion effect pada stabilitas sistem keuangan biasanya berkaitan pada aktivitas sistem pembayaran dan lintas batas aliran keuangan sebagai akibat dari globalisasi keuangan (Trihadmini, 2011). Apabila kelancaran sistem pembayaran terganggu akibat gagal bayar (failure to settle) maka akan menimbulkan contagion effect dan selanjutnya menimbulkan gangguan yang bersifat sistemik pada sistem keuangan. Ada beberapa indikator yang mampu merepresentasikan contagion effect. Dari 3 (tiga) indikator contagion effect kaitannya dengan stabilitas sistem keuangan di Indonesia, hasil bobot terbesar adalah Korelasi Pasar Keuangan (0.358), dan Sektor Ekonomi yang Jatuh (0.331). Berikutnya adalah Trade Spilover (0.311).

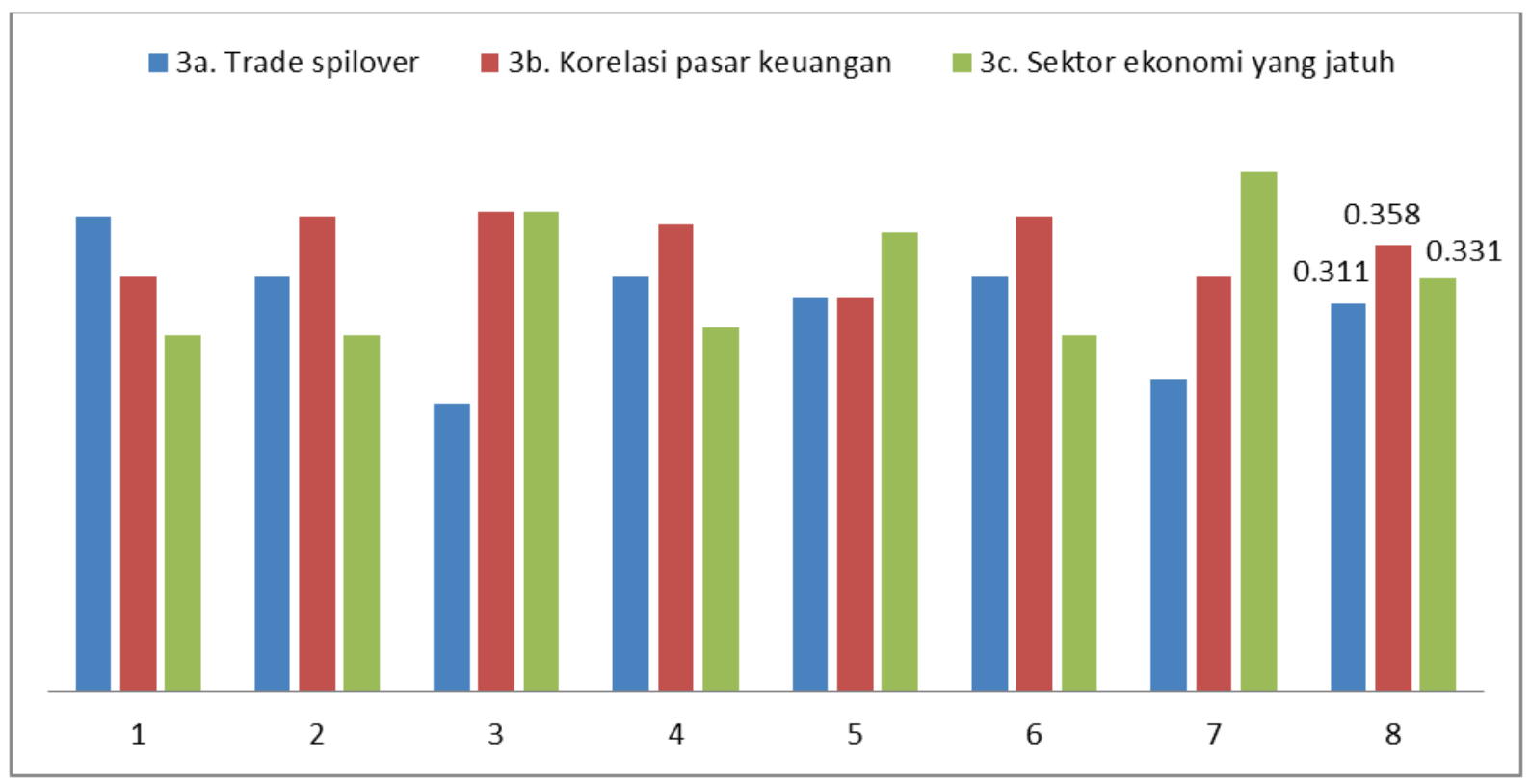

Gambar 4.4 Indikator Contagion Effect 
Sebagai salah satu tugasnya dalam menjaga stabilitas sistem pembayaran, Bank Indonesia harus mengupayakan terwujudnya stabilitas pasar keuangan sehingga diharapkan sistem pembayaran dapat berjalan dengan lancar. Hal ini dikarenakan risiko contagion effect yang ditimbulkan oleh sistem pembayaran cenderung meningkat. Salah satu upaya untuk mengatasi hal ini adalah Bank Indonesia mengembangkan mekanisme sistem pembayaran yang bersifat real time yang dinamakan dengan sistem RTGS (Real Time Gross Settlement). Diharapkan sistem ini mampu lebih meningkatkan keamanan dan kecepatan sistem pembayaran.

Seperti halnya dengan krisis ekonomi dan keuangan global yang terjadi pada tahun 2008 lalu, sektor ekonomi yang jatuh juga dapat memicu terjadinya contagion effect dari satu negara ke negara lain. Dengan adanya globalisasi keuangan, jatuhnya sektor ekonomi yang terjadi pada satu negara akan cepat menular ke negara-negara lain. Oleh karena itu, dibutuhkan kewaspadaan dan strategi-strategi antisipastif oleh tiap-tiap bank sentral di tiap-tiap negara. Selain sektor ekonomi yang jatuh, contagion effect dapat terjadi pula akibat meluasnya aktivitas perdagangan (trade spillover) hingga pada taraf internasional. Dari aktivitas perdagangan inilah, segala indikatorindikator ekonomi pada satu negara akan menular ke negara lain, seperti tingkat suku bunga, tingkat inflasi, kurs mata uang, dan lain sebagainya.

Dari 3 (tiga) indikator Contagion Effect kaitannya dengan stabilitas sistem keuangan di Indonesia, hasil bobot terbesar adalah Korelasi Pasar Keuangan (0.358), dan Sektor Ekonomi yang Jatuh (0.331). Berikutnya adalah Trade Spilover (0.311). Korelasi pasar keuangan merupakan faktor utama yang memengaruhi contagion effect. Contagion effect muncul sebagai konsekuensi adanya globalilasi pada sistem keuangan. Korelasi antarpasar keuangan mempunyai peranan penting dalam menjaga kelancaran pada sistem pembayaran. Terlebih lagi pada kondisi globalisasi keuangan saat ini, dimana pasar keuangan yang terhubung tidak hanya pasar keuangan yang ada di dalam negeri saja tetapi juga pasar keuangan yang lebih luas lagi, yaitu pada taraf internasional (korelasi antara pasar keuangan Indonesia dengan pasar keuangan internasional), baik dari sisi pelaku pasar yang terlibat maupun institusinya. Semakin kuat pertalian (korelasi) antarpasar keuangan di dunia maka semakin tinggi pula peluang terjadinya contagion effect. Untuk mengantisipasi terjadinya hal-hal yang tidak diinginkan, Bank Indonesia sebagai bank sentral perlu meningkatkan kewaspadaan dalam menyikapi volatilitas pada pasar keuangan regional terdekat.

\section{Aspek Utang}

Selanjutnya, dari 3 (tiga) indikator Utang kaitannya dengan stabilitas sistem keuangan di Indonesia, hasil bobot terbesar adalah Utang Jatuh Tempo (0.341), dan Rasio Utang Luar Negeri terhadap Produk Domestik Bruto/PDB (0.38). Berikutnya adalah Pinjaman Luar Negeri (0.321).

Pengelolaan atas utang (debt) merupakan hal yang penting untuk diperhatikan dalam upaya menjaga stabilitas sistem keuangan di Indonesia. Terlebih lagi, Indonesia mempunyai catatan utang luar negeri yang cukup signifikan. Keputusan pengambilan utang dan strategi pelunasannya harus diatur sedemikian rupa agar tidak menggangu stabilitas sistem keuangan di Indonesia. Keputusan pengambilan utang luar negeri mempunyai dampak positif sekaligus dampak negatif bagi stabilitas sistem keuangan di Indonesia.

Utang jatuh tempo merupakan jumlah utang atau kewajiban yang telah sampai pada batas waktu pembayaran. Utang jatuh tempo dikategorikan sebagai utang lancar. Berdasarkan hasil wawancara dan analisis data dalam penelitian ini, utang lancar memilki hubungan yang kuat terhadap pemeliharaan stabilitas sistem keuangan di Indonesia. Pelunasan utang jatuh tempo dengan segera akan cukup membantu untuk menjaga stabilitas keuangan di Indonesia.

Gambaran lain yang mencerminkan utang (debt) adalah pinjaman luar negeri. Ada beberapa faktor yang menjadi pertimbangan untuk melakukan pinjaman luar negeri dibandingkan dengan pinjaman dalam negeri, antara lain: biaya pengembalian lebih ringan, potensi untuk melakukan pinjaman di luar negeri lebih tinggi daripada dalam negeri, hubungan diplomatis antarnegara, dan lain sebagainya. Hal yang 
perlu diperhatikan dalam melakukan pinjaman luar negeri adalah kurs mata uang dan tempo pinjaman. Melakukan pinjaman luar negeri sangat diperbolehkan jika memang menguntungkan dan diperlukan untuk menjaga stabilitas ekonomi dalam negeri. Batas standar pinjaman luar negeri yang diperbolehkan agar stabilitas ekonomi dalam negeri tetap terjaga adalah dengan membandingkan output yang dihasilkan atas aktivitas pinjaman tersebut. Hal ini diproksikan dengan nilai PDB, yaitu dengan cara menghitung rasio utang luar negeri terhadap Produk Domestik Bruto/PDB. Batas pinjaman atau utang luar negeri yang diperbolehkan adalah tidak lebih besar dari nilai PDB sehingga stabilitas ekonomi tetap terjaga.

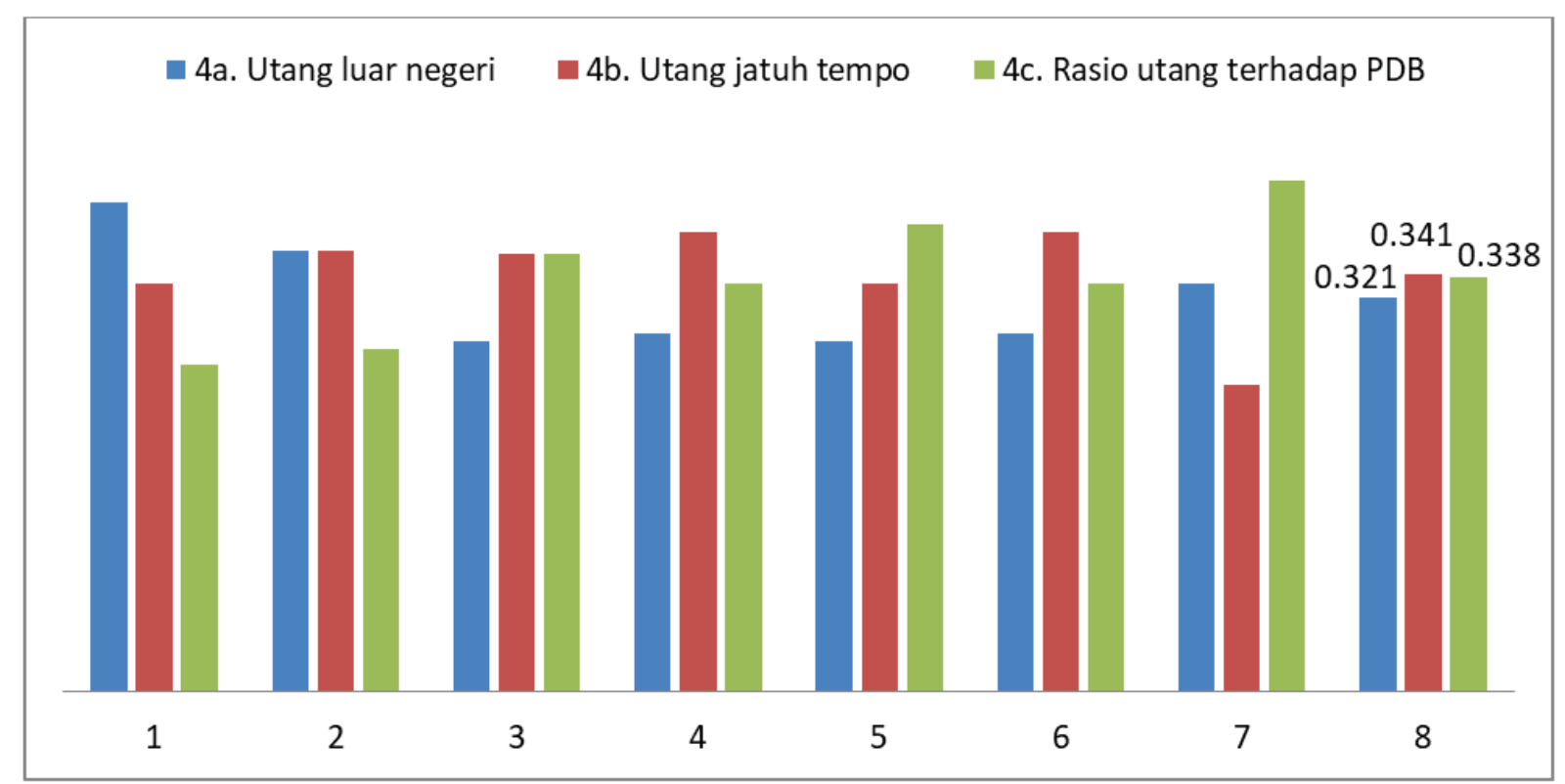

Gambar 4.5 Indikator Utang

\section{Aspek Tenaga Kerja}

Aspek yang tidak kalah penting lainnya adalah terkait aspek tenaga kerja. Dari 3 (tiga) indikator Labor Aspects kaitannya dengan stabilitas sistem keuangan di Indonesia, hasil bobot terbesar adalah Employment Rate (0.351), dan Pasar Tenaga Kerja (0.346). Berikutnya adalah nilai Average Annual Wages (0.304).

Aspek tenaga kerja memiliki pengaruh penting dalam pegelolaan dana investasi dan keuangan. Employment rate dan unemployment rate menunjukkan seberapa banyak tinggi jumlah angkatan kerja yang bekerja dan jumlah angkatan kerja yang tidak bekerja (tingkat pengangguran). Tingginya nilai employment rate mengindikasikan bahwa jumlah lapangan kerja mampu menyerap jumlah tenaga kerja secara optimal. Sebaliknya, tingginya nilai unemployment rate menunjukkan bahwa jumlah lapangan kerja tidak terserap secara maksimal di pasar tenaga kerja.
Ada banyak faktor yang memengaruhi hal tersebut, diantaranya: jumlah lapangan kerja yang kurang, tenaga kerja yang tidak memenuhi kualifikasi, dan lain sebagainya. Tingginya tingkat pengangguran mengindikasikan tingkat pendapatan rumah tangga akan berkurang dan bahkan akan bernilai nol sama sekali. Akibatnya, hal ini dapat mengganggu pola konsumsi rumah tangga yang selanjutnya akan menggangu tingkat produksi total suatu negara. Selain itu, tingginya tingkat pengangguran juga akan memicu tingginya tingkat kriminalitas. Implikasinya dari dua kondisi tersebut adalah bahwa secara tidak langsung akan mengganggu stabilitas ekonomi dan sistem keuangan suatu negara. Hal yang sama juga dijelaskan oleh Moinescu (2008) dalam penelitiannya, dimana Moinescu melihat adanya dampak positif yang signifikan antara tingkat pengangguran dengan stabilitas perbankan di Romania. Kenaikan pada tingkat pengangguran 
akan menyebabkan terjadinya kontraksi dalam tingkat pendapatan dan kapasitas konsumsi dalam rumah tangga. Selanjutnya, hal ini akan memicu terjadinya peningkatan pada tingkat gagal bayar dan meningkatkan kredit bermasalah (NPL) pada industri perbankan. Berdasarkan hasil indepth, permintaan dan penawaran tenaga kerja pada pasar tenaga kerja akan berpengaruhi pada penentuan nilai average annual wages. Jika permintaan tenaga kerja lebih besar dari penawaran tenaga kerja, maka akan meningkatkan nilai average annual wages dan sebaliknya.

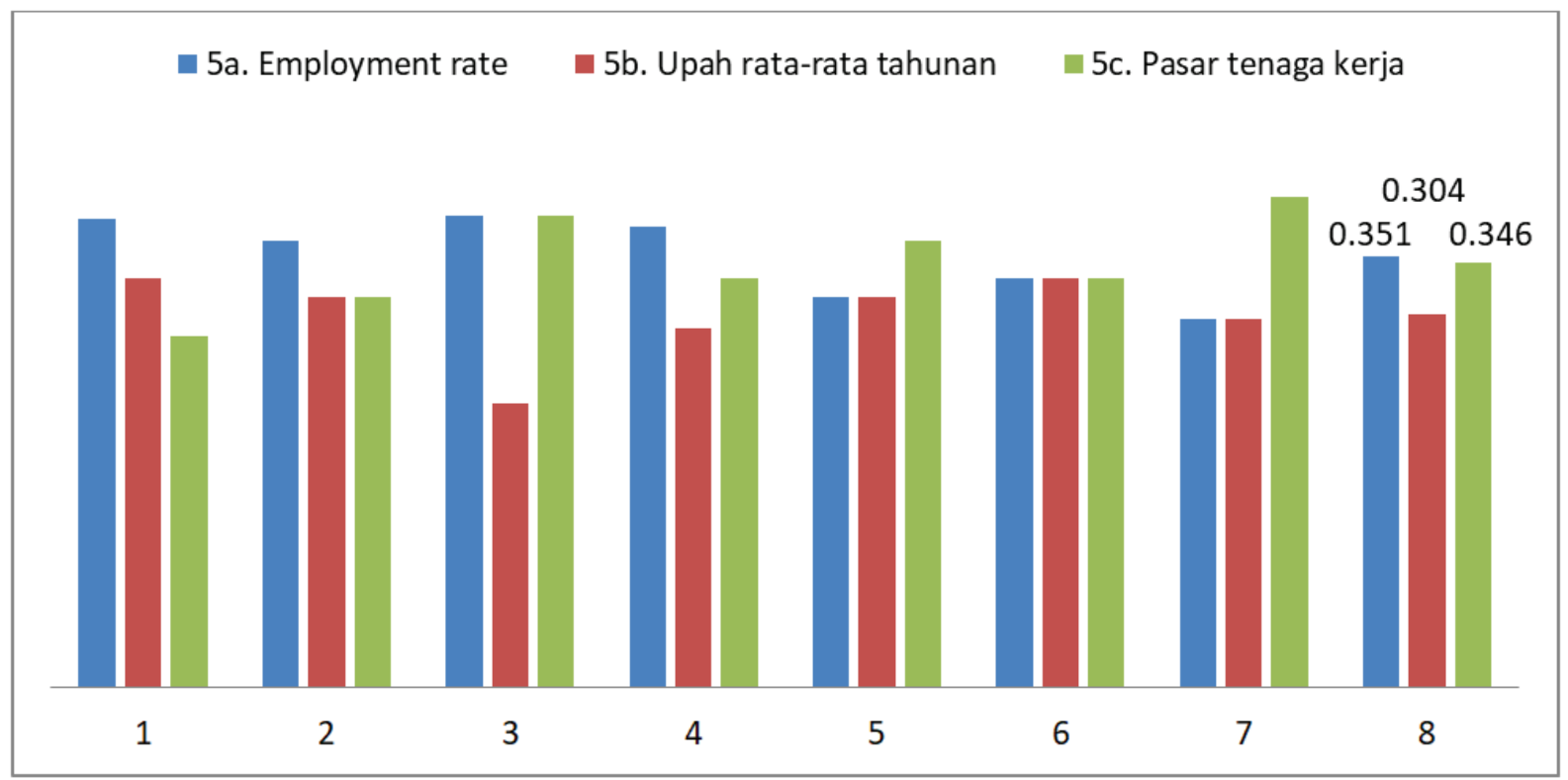

Gambar 4.6 Indikator Tenaga Kerja

\section{KESIMPULAN DAN SARAN}

Berdasarkan hasil wawancara dengan para pakar praktisi perbankan, terkait indikator terpenting stabilitas sistem keuangan di Indonesia dalam aspek makroprudensial, yang menjadi 3 (tiga) aspek terpenting adalah aspek utang $(0,225)$, indikator makroekonomi $(0,222)$ dan aspek neraca pembayaran $(0,217)$. Keputusan pengambilan utang dan strategi pelunasannya harus diatur sedemikian rupa agar tidak menggangu stabilitas sistem keuangan di Indonesia. Hal ini lebih relevan dengan teori krisis keuangan generasi ketiga yang menyebutkan bahwa ketergantungan antarnegara dapat memberikan peranan terhadap krisis ketika ketidakmampuan suatu negara untuk membayar utang luar negeri. Sementara itu aspek kedua dan ketiga yakni indikator makroekonomi dan neraca pembayaran relatif lebih sesuai dengan teori krisis generasi kedua yang dikemukakan oleh Obstfeld (1996). Dari hasil temuan penelitian, pihak berkepentingan baik Bank Indonesia, Otoritas Jasa Keuangan berikut juga Lembaga
Penjamin Simpanan, perlu mencermati indikatorindikator yang dianggap paling penting menurut perspektif praktisi perbankan dan keuangan pada umumnya sehingga kebijakan yang akan diambil pada masa mendatang dapat secara tepat dan cepat dieksekusi.

Kebijakan makroprudensial berikut mikroprudensial yang dikeluarkan oleh Bank Indonesia sebagai bank sentral yang mempunyai kewenangan penuh, sangat berperan penting dalam menjaga Stabilitas Sistem Keuangan (SSK). Kehadiran Forum Koordinasi Stabilitas Sistem Keuangan (FKSSK) yang terdiri dari beberapa otoritas keuangan diharapkan mampu menyelamatkan kondisi perekonomian bangsa Indonesia dalam sektor keuangan. Sinergi Kebijakan Mikro dan Makroprudensial pun diharapkan terus mampu menjaga inflasi yang mampu memberikan stabilitas perekonomian. Meskipun pada prosesnya, Kebijakan Makroprudensial tidak bisa lepas dari Kebijakan Moneter yang ada pada Bank Indonesia juga. Apalagi bersinergi dengan Kebijakan 
Mikroprudensial, dalam menjaga Stabilitas Sistem Keuangan (SSK) akan semakin sehat untuk mengantisipasi berbagai gejolak ekonomi atau krisis global yang terjadi secara tidak terduga di masa yang akan datang. Untuk penelitian selanjutnya, penelitian ini diharapkan menjadi pijakan awal dalam riset ke depan. Umpamanya dengan lebih memperluas jumlah responden pakar yang bukan hanya berasal dari praktisi perbankan tetapi juga dari akademisi dan pemangku kebijakan sendiri sehingga diharapkan hasilnya menjadi lebih kaya dan bersifat 'helicopter view'

\section{UCAPAN TERIMA KASIH}

Penelitian ini dibiayai oleh dana hibah yang bersumber dari Lembaga Penjamin Simpanan (LPS) Republik Indonesia periode tahun 2018. Paper ini adalah bagian dari laporan lengkap yang berjudul "Manakah Indikator Terpenting Stabilitas Sistem Keuangan: Aplikasi Metode Analytic Network Process".

\section{DAFTAR PUSTAKA}

Ari, Ali and Rüstem Dağtekin. (2008). Early Warning Signals of The 2000/2001 Turkish Financial Crisis. MPRA Paper, No. 25857.

Ascarya, Cahyono, W., and Syarifuddin, F. (2012). The Anatomy of Financial Crisis and how to Prevent it: The Case of Dual Financial System in Indonesia. BI Working Paper. WP/19/2012.

Ascarya. (2005). Analytic Network Process (ANP): Pendekatan Baru Studi Kualitatif. Jakarta: Pusat Pendidikan dan Studi Kebanksentralan, Bank Indonesia.

Badan Pusat Statistik, www.bps.go.id

Bank Indonesia. (2009a). Outlook Ekonomi Indonesia 2009-2014, edisi Januari 2009.

Bank Indonesia. (2009b). Outlook Ekonomi Indonesia : Krisis Finansial Global dan Dampaknya terhadap Perekonomian Indonesia. Jakarta: Biro Riset Ekonomi, Direktorat Riset Ekonomi dan Kebijakan Moneter.

Bank Indonesia. (2011). Gerai Info Edisi XV. Juni 2011.
Bank Indonesia. (2017). Statistik Sistem Keuangan Indonesia.

Barrel, R., Davis, E.P., Karim, D., and Liadze, I. (2010). Bank regulation. Property Prices and Early warning Systems for Banking Crises in OECD Countries. Journal of Banking \& Finance, 34(9), 2255-2264.

Boyd, J., De Nicolo, G., and Loukoianova, E. (2009). Banking Crises and Crisis Dating: Theory and Evidence. IMF Working Paper. WP/09/141.

Brooks, D.H., Kurmanalieva, E., and Yang, D.Y. (2016). Trade, Trade Finance and Global Liquidity in Asia: Markov-Switching FAVAR Approach. East Asian Economic Review, 20(3), 339-363.

Bucevska, Vesna. (2011). An Analysis of Financial Crisis by an Early Warning System Model: The Case of The EU Candidate Countries. Businesss and Economic Horizons, 4(1), 13-26.

Caprio, G., Klingebiel, D., Laeven, L., and Noguera, G. (2005). Banking Crises Database, in Systemic Financial Crises. P. Honahan and L. Laeven eds. Cambridge, UK: Cambridge University Press.

Čihak, M., and Hesse, H. (2008). Islamic Bank and Financial Stability: An Empirical Analysis. IMF Working Paper. WP/08/16.

Demirgüç-Kunt \& Detragiache. (1998). The Determinants of Banking Crises: Evidence from Developing and Developed Countries. IMF Staff Paper, 45(1).

Frankel, Jeffrey A. dan Rose, Andrew K. (1996). Currency crashes in emerging markets: An empirical treatment. Journal of International Economics, 41(3-4), 351-366.

Goldstein, Moris. (2000). Assesing Financial Vulnerability: An Early Warning System for Emerging Markets. MPRA Paper, No. 13629.

Gujarati, Damodar N. (2003). Basic Econometrics. Forth Edition. New York, USA: McGrawHill.

Hadad, M.D., Santoso, W., Sarwedi, Sukarno, H., dan Adenan, M. (2003). Indikator Awal Krisis Perbankan. Desember 2003. http:// 
www.bi.go.id/NR/rdonlyer/2DAB2C92BF34-4DE4-A3EF2078CC77431/7822/ IndikatorAwalKrisisPerbankan.pdf

Hagen, Jürgen von and Ho, Tai-kuang. (2004). Money Market Pressure and The Determinants of Banking Crises. Journal of Money, Credit and Banking, 39(5).

Hardy, Daniel C. dan Ceyla Pazarbasioglu. (1999). Determinants and Leading Indicators of Banking Crises: Further Evidence. IMF Staff Paper, 46(3).

Ho, W. (2008). Integrated analytic hierarchy process and its applications: A literature review, European Journal of Operational Research, 186(1), 211-228.

Imansyah, Muhammad Handry. (2009). Krisis Keuangan di Indonesia. Dapatkah Diramalkan? Jakarta: Elex Media Komputindo.

Imansyah, M.H., dan Abimanyu, A. (Ed). (2008). Sistem Pendeteksian Dini Krisis Keuangan di Indonesia: Penerapan Berbagai Model Ekonomi. Yogyakarta: BPFE UGM.

Islahi, Abdul Azim. (2013). Economic and Financial Crises in Fifteenth Century Egypt: Lessons from the history. Islamic Economic Studies, 21(2), 71-94.

Kaminsky, G., Lizondo, S., and Reinhart, C.M. (1997). Leading Indicators of Currency Crises. IMF Staff Paper, 45(1).

Kaminsky, Graciela L. \& Reinhart, C.M. (1999). The Twin Crisis: The Cause of Banking and Balance Payments Problems. The American Economic Review, 89(3), 473-500.

Kemu, Suparman Zen dan Almizan Ulfa. (2008). Model Non-Parametrik Early Warning System Sektor Keuangan Indonesia. Jurnal Keuangan \& Moneter, 8(1).

Krolzig, Hans-Martin. (1997). Markov-Switching Vector Autoregression Modelling, Stastical inferencel, and Application to Business Cycle Analysis. New York: Springer-Verlag Berlin Heidelberg.

Leaven, Luc and Valencia, F. (2008). Systemic Banking Crises: A New Database. IMF Working Paper. WP/08/224.
Lee, M.C. (2010). The analytic hierarchy and the network process in multicriteria decision making: Performance evaluation and selecting key performance indicators based on ANP model, Convergence and Hybrid Information Technologies, Book edited by Marius Crisan. Croatia: INTECH.

Norgren, Claes. (2010). The Cause of The Global Financial Crisis and Their Implication for Supreme Audit Institutions. Stockholm: Swedish National Audit Office.

Nurfalah, I., Rusydiana, A.S., Laila, N., and Cahyono, E.F. (2018). Early warning to banking crises in the dual financial system in Indonesia: The markov switching approach. JKAU: Islamic Economics, 31(2), 133-156.

Otoritas Jasa Keuangan, www.ojk.go.id

Otoritas Jasa Keuangan. (2017). Booklet Perbankan Indonesia 2017. Jakarta: Departemen Perizinan dan Informasi Perbakan, Otoritas Jasa Keuangan.

Radyati, Maria R. Nindita. (2012). Keuangan Inklusif Perbankan. Published on Universitas Trisakti. MMCSR \& MMCE. http://www. mmcrusakti.org

Reinhart, C.M., and Rogoff, K.S. (2008). This Time Is Different: A Panoramic View of Eight Centuries of Financial Crises. NBER Working Paper No. 13882.

Rusydiana, A.S., and Devi, A. (2018). Elaborating cash waqf development in Indonesia using analytic network process. International Journal of Islamic Business and Economics, 2(1), 1-13.

Rusydiana, A.S., and Devi, A. (2013). Challenges in Developing Baitul Maal wat Tamwiil in Indonesia using Analytic Network Process. Business Management Quarterly Review, 4(2), 51-62.

Rusydiana, A.S. (2016). Analisis masalah pengembangan perbankan syariah di Indonesia: Aplikasi metode analytic network process. Esensi: Jurnal Bisnis dan Manajemen, 6(2), 237-246.

Rusydiana, A.S. (2009). Determinan Inflasi Indonesia: Perbandingan Pendekatan Islam dan Konvensional. Journal of Islamic Business and Economics, 3(1), 1-42. 
Saaty, Thomas L. (2001). Decision Making with Dependence and Feedback: The Analytic Network Process. Pittsburgh: RWS Publication.

Saaty, T.L., and Vargas, L.G. (2006). Decision Making with the Analitic Network Process. Economic, Political, Social and Technological Applications with Benefits, Opportunities, Costs and Risks. Pittsburgh: Springer, RWS Publication.

Sachs, Jeffrey D., and Velasco, A. (1996). Financial Crises in Emerging Markets: The Lessons From 1995. Brooking Papers on Economic Activity, No. 1.

Shen, Chung-Hua and Hsienh, Meng-Fen. (2003). Predicting of Bank Failures Using Combined Micro and Macro Data. Taiwan: National University Chengchi.
Sipahi, S. and Timor, M. (2010). The analytic hierarchy process \& analytic network process: An overview of applications. Management Decision, 48(5), 775-808.

Shah, S.Z.A., and Bhutta, N.T. (2016). Does Islamic Finance Prevent Financial Crises: A Global Perspective. Journal of Finance, Accounting and Management, 7(2), 31-38.

Suta, I. P. G. A., dan Musa, S. (2003). Membedah Krisis Perbankan Anatomi Krisis dan Penyehatan Perbankan: Cetakan Pertama. Jakarta: SAD Satria Bakti.

Yang, Bin. (2017). Stock Market Crash, New Market Failure Theory and Extremely Great Economic and Financial Crises. World Review of Political Economy, 8(1).

Zhuang, Juzhong. (2005). Nonparametric EWS Models of Currency and Banking Crises for East Asia in Early Warning System for Financial Crises: Application to East Asia. London: Palgrave, Macmillan. 


\section{LAMPIRAN}

\begin{tabular}{|c|c|}
\hline MAKROPRUDENSIAL & NILAI EIGENVALUE \\
\hline 1. Neraca Pembayaran & 0.217 \\
\hline 2. Indikator Makroekonomi & 0.222 \\
\hline 3. Efek Domino (Contagion Effect) & 0.178 \\
\hline 4. Utang & 0.225 \\
\hline 5. Aspek Tenaga Kerja & 0.159 \\
\hline \multicolumn{2}{|l|}{ NERACA PEMBAYARAN } \\
\hline 1a. Defisit neraca berjalan & 0.230 \\
\hline 1b. Kecukupan cadangan devisa & 0.220 \\
\hline 1c. Term of Trade (ToT) & 0.161 \\
\hline 1d. Komposisi \& jangka waktu aliran modal & 0.198 \\
\hline 1e. Nilai ekspor-impor & 0.192 \\
\hline \multicolumn{2}{|l|}{ INDIKATOR MAKROEKONOMI } \\
\hline 2a. Pertumbuhan ekonomi & 0.156 \\
\hline 2b. Volatilitas inflasi & 0.137 \\
\hline 2c. Volatilitas suku bunga & 0.154 \\
\hline 2d. Volatilitas nilai tukar & 0.157 \\
\hline 2e. Inflasi rumah tangga & 0.129 \\
\hline 2f. Suku bunga domestik & 0.125 \\
\hline 2g. Suku bunga The Fed & 0.142 \\
\hline \multicolumn{2}{|l|}{ CONTAGION EFFECT } \\
\hline 3a. Trade spilover & 0.311 \\
\hline 3b. Korelasi pasar keuangan & 0.358 \\
\hline 3c. Sektor ekonomi yang jatuh & 0.331 \\
\hline \multicolumn{2}{|l|}{ UTANG } \\
\hline 4a. Pinjaman luar negeri & 0.321 \\
\hline 4b. Utang jatuh tempo & 0.341 \\
\hline 4c. Rasio utang LN terhadap PDB & 0.338 \\
\hline \multicolumn{2}{|l|}{ ASPEK TENAGA KERJA } \\
\hline 5a. Employment rate & 0.351 \\
\hline 5b. Upah rata-rata tahunan & 0.304 \\
\hline 5c. Pasar tenaga kerja & 0.346 \\
\hline
\end{tabular}

